\title{
Social Problems in Short Stories entitled Mata Yang Enak Dipandang by Ahmad Tohari and its Relevance in Senior High School
}

\author{
Agus Yuliyanto*), \\ Universitas Sebelas Maret \\ Suyitno*), \\ Universitas Sebelas Maret \\ Muhammad Rohmadi *), \\ Universitas Sebelas Maret \\ *)Correspondences author: J1. Ir. Sutami 36A Surakarta, Jawa Tengah, Indonesia \\ e-mail:agusyuliyantoagus@gmail.com
}

\begin{abstract}
This research was based on the view that literature is basically a reflection of society. So in this study, researchers used the approach to the sociology of literature. This paper aimed to describe (1) short story becomes one of the literary works that are used as teaching material in schools, (2) the aspect of characrter education based on the collection of short stories entitled Mata Yang Enak Dipandang by Ahmad Tohari, and (3) social problems collection of short stories entitled Mata Yang Enak Dipandang. The method used in this research is qualitative descriptive explaining the data that has been found in research. The main data sources in this study the quotations contained in the novel and the results of interviews with literary experts and learning experts. The results of this study is the main characters in this short story are varied and its can be utilized in the study of literary appreciation for Class XI in Senior high school semester with the standard literary discourse understanding competence through reading poetry and short stories in the aspects of reading and basic competence that is analyzing the intrinsic elements of a short story linkages with everyday life
\end{abstract}

Keywords: sosiology, collection of short story, teaching materials, senior high school

\begin{abstract}
Article History:Received: 22/10/2017; Revised: 19/11/2017; Accepted: 27/11/2017; Published: 20/12/2017
How to Cite (MLA $7^{\text {th }}$ ): Yulianto, Agus, Suyitno and Muhammad Rohmadi. "Social Problems in Short Stories entitled Mata Yang Enak Dipandang by Ahmad Tohari and its Relevance in Senior High School." Hortatori Jurnal Pendidikan Bahasa dan Sastra Indonesia 1.2 (2017): 140-145. Print/Online. Copyrights Holder: Yulianto, Agus, Suyitno and Muhammad Rohmadi. First Publication: Hortatori Jurnal Pendidikan Bahasa dan Sastra Indonesia (2017).
\end{abstract}

\section{Introductions}

A literary work is the result of a writer's creativity about ideas, thoughts or opinions about a good thing he hears from others or what he sees and feels for himself, packed in such a way that the person who enjoys the literary work can understand the author's intent. In a literary work often found events and problems that are told, because the shrewdness and ability of the author's imagination, it looks concrete and like it really exists and happens. Moreover, if supported by the background and the characters of convincing stories, for example deliberately associated with historical truth, the story will be more convincing readers. The reader seems to find something as he encounters in the realm of reality, then the events or things told in the story are no longer perceived as stories, as manifestations of imaginative 
events, but are regarded as factual in fact real world. Therefore, it is not wrong to say literary works as a reflection of society.

Literary works appear in the background of the basic human impulse to express its existence. The work of fiction literature tells the various problems of human life in its interaction with oneself, and its interaction with God (Nurgiyantoro, 2005). The literary works are meant among others poetry and prose. Through these two types of literary works, man can tell others about his life and his interactions with himself, his fellow human beings, or with his God. Short story as one type of fictional prose plays a lot in delivering messages in life because the majority of short stories raise issues about social life, society, and culture. This is also recognized by Ratna (2007) which states that the short story is considered as the most dominant literary work in presenting the social elements. The intrinsic element will discuss what is contained in the novel such as plot, theme, plot, setting, character, character, point of view, and style of language. Extrinsic element in a short story is the elements from outside the literary works that can indirectly berpegaruh such as sociology, philosophy, religion, politics, culture, and others (Endraswara, 2008).

Literature as a text can not escape the role of knowledge and the creation of literary works. Elements of literary works, such as authors and their environment, are integrated with the culture they adopt, so that literary works can be viewed as social images of society at any given time in relation to social matters. Similarly disclosed Jacques Leenhart (1967: 530) who examines that literature is a product as well as part of the social reality of society. This is in line with the results of Silvia Albertazzi's research (2010: 8-9) which states the same reality if literature is a reflection of society, authors serve as observers and assessors.

A Short story becomes one of the literary works that are used as teaching material in schools, particularly the class XI Senior High School. With short story, students can reap positive things contained in the short story so that it can serve as educators in addition to teachers. Teaching the short story material is expressly contained in the composition of the Basic Competence (KD) Curriculum revision 2013 in 2016. The material contained in the KD 3.1 and 4.1. KD 3.1 contains material that requires that students meet the competence in identifying information, which includes orientation, a series of interconnected events, complications and resolution, in the story of history (novel) an oral or written, and KD 4.1 students required to meet the competency mengonstruksi the values of historical story information in a text.

Learning literature that actually aims to build character in young learners. Hardiningtyas (2008:103) stated that the study of literature aims to instill moral values, ethics, manners, and humanity on learners. Referring to the opinion, teachers should be able to inflate it the quality of personality of students through the learning of novel appreciation from various sources both from Indonesia short story, novel, or translations of foreign novels, as well as laden with cultural areas, such as culture Java (Saddhono and Rohmadi, 2014). Therefore, knowledge, skills, and insights of teachers need to be honed. Mastery of the material about the literary work of any crpen need to be controlled by the teacher. In addition, teachers must also look at the ability in selecting and presenting material on the short stories of appreciation learning HIGH SCHOOL level.

The collection of short Stories entitled Mata Yang Enak Dipandang is one of Ahmad Tohari's works. Mata Yang Enak Dipandang is a collection of short stories containing fifteen works of Ahmad Tohari spread in print media between 1983 and 1997. Like his novels, his short stories have their own characteristics. He always lifts the lives of the little people or the lower classes with all the tricks. In addition, the author's life view may be related to the educational background of the author. The reason why researchers make a collection of short stories that are eye-catching Ahmad Tohari's work is that most researchers who analyzed the work of Ahmad Tohari took a novel object in his research, especially Ronggeng Dukuh Paruk, and quite a few who examine his short stories when the short stories made by Ahmad Tohari also very worthy to be studied. However, the most important reason why using Mata Yang Enak Dipandang is a collection of short stories raised a lot of social problems that can help students to know what kind of social problems that are in their environment other than that students can shape the character of students such as caring, responsibility, tolerance, and wise in looking at an event they encounter in their environment. The research was based on the view that literature is basically a reflection of society. So in this study, researchers used the approach to the sociology of literature. A multidisciplinary approach that examines the relationships among conditions of community social life with literary work. Based on the background of the above then this research took the title of "social 
problems in the collection of short stories entitled Mata yang Enak Dipandang by Ahmad Tohari and relevance to the Teaching Materials in Senior High School." The study of sociology of literature was introduced in the 1970s to the 1980s (Singer, 2011). Meanwhile, the study of sociology of literature is a branch of literary research that is reflective. This research is much in demand by researchers who want to see literature as a mirror of community life (Suwardi, 2008). In his writings, it is described that this study is chronologically demonstrated by Griswold which states that the study of sociology of literature such as amoeba, has no definite structure but can be attributed to anything (Griswold 1992). This opinion reinforces the opinion of researchers related to the study of sociology of literature, the study of sociology of literature will basically learn about the study contained in society and the surrounding environment. The statement is reinforced by Damono's (1979) opinion which states one approach in literary studies that understands and evaluates literary works by considering societal (social) aspects. The aim of the study or study of sociology in literature is to obtain a complete picture of the relationship between authors, literary works, and society (Pradopo 1993). This means showing that the study of sociology of literature becomes a study that has a broad field to study a literary work. Literary works in the form of poetry and prose of course have a relationship with the community so that the points in it can have implications to the community (Saddhono and Supeni, 2014). Sociology of literature is the cornerstone of the theory that analyzes the problems concerning the relationship between literature and society. Sociology is trying to answer the question of how society is made possible, how it works, and why the people live.

\section{Method}

The research is research descriptive qualitative approach to psychology literature. Short story as of a literary work who have a structural, psychological of literature, and character education capable of examined in the contents of analysis. Through "triangluasi" the theory and speakers, this research validated in comprehensive so that get the data is credible. The whole process are systematic with a model analysis flowing (Miles \& Hubberman , 1992: 20).

In concrete terms, research started with read a whole of short story entitled Mata Yang Enak Dipandang by Ahmad Tohari. After read and understand the contents of the short story, researchers continue by choosing data by means of purposive, namely chose him based on consideration from a focus research psychology this literary, among other elements intrinsic, extrinsic, and implications in the community of the novel. Then, through data sources also of informants obtained secondary data enrich data in this research.

Test validity in this research completed in three triangulation. Third triangulation these include: (1) triangulation theories; (2) triangulation data sources; and (3) triangulation researchers. Through step test the validity of the researchers it would be easier to get data and validity of the theory as a references of this research. Triangulation data source is a technique to harmonize the truth of the data the results of the analysis by interviews distinct sources, but discuss the same thing.

\section{Result and Discussions}

Swingewood (in Wiyatmi, 2008) outlines that sociology is a scientific and objective study of man in society, the study of social institutions and processes. The general form of social processes is social interaction, which is a major requirement of social activities, especially of social interaction. Social interaction is a dynamic social relationship involving relations between individuals, between human groups, and between individuals and groups of people (Soekanto, 1982). The analysis of the sociology of literature can not be separated from structural analysis, this is because the literary work is a meaningful structure. Literary literature in the approach of literary sociology basically begins at the two fulcrum of fission. The first focal point assumes that literary texts are the subject of analysis work in the form of an understanding of structure. The second point of the fulcrum is the assumption that literature is a mirror of the process of social interaction. Both sociology and literature have the same object of study, that is, human beings in society, understanding the relationships between humans and the processes that lead from these relationships in society. Sociology and literature have the same object of literature in society, but essentially between sociology and literature have differences, sociology only limits itself to what 
happens today, not what should happen, whereas literature is more evaluative, subjective and imaginative (Ratna, 2003).

From these quotations it can be concluded that sociology and literature are always related to society. The term sociology of literature applies to the writings of critics and literary historians whose primary concern is on the ways in which an author is influenced by his class status, societal ideology, economic circumstances pertaining to his work and the type of intended reader (Abrams, 1981).

Goldmann developed the sociology of literature to unify structural analysis with historical and dialectical matrealism. Literary works should be understood as meaningful totality. The major works of literature and philosophy have a total cohesion and the elements that make up the text mean when it can provide a complete and coherent picture of meaning. In this case literature is a fact which has the same position as in scientific research pioneered by Hippolyte Taine. This view says that literature is not just a reflection of its society, literature is a human effort to discover the world's meaning of the values contained in it. Those values must be lived by people and society (Faruk, 2010). Sociology and literature have the same object of literature in society, but essentially between sociology and literature have differences, sociology only limits itself to what happens today, not what should happen, whereas literature is more evaluative, subjective and imaginative (Ratna, 2003). From these quotations it can be concluded that sociology and literature are always related to society. The term sociology of literature applies to the writings of critics and literary historians whose primary concern is on the ways in which an author is influenced by his class status, societal ideology, economic circumstances pertaining to his work and the type of intended reader (Abrams, 1981 ). Goldmann developed the sociology of literature to unify structural analysis with historical and dialectical matrealism. Literary works should be understood as meaningful totality. The major works of literature and philosophy have a total cohesion and the elements that make up the text mean when it can provide a complete and coherent picture of meaning.

In this case literature is a fact which has the same position as in scientific research pioneered by Hippolyte Taine. This view says that literature is not just a reflection of its society, literature is a human effort to discover the world's meaning of the values contained in it. Those values must be lived by people and society (Faruk, 2010). Swingewood (1972) divides the sociology of literature on four sections; (1) sociology and literature: a possible approach in this regard sees literary works as cultural documents reflecting an age, the position of an author and the acceptance of a work of a particular author; (2) social theories about literature: the approach is done with Hippolyte Taine's theory, Marxist theory and the background of a work; (3) literature and structuralism: the approach that connects the Russian formalime and Prague linguistic flow is called the genetic structuralism of Lucien Goldmann; and (4) the problem of the method: positivism approach, the work is considered as a document that records the socio-cultural and dialectical elements, the cultural element in a work is not every element, but the whole is unity.

Sociology is a common societal science which is the final result of the development of science. Sociology was born at the last moment of the development of science. Because sociology is based on the advances that other sciences have achieved. Sociology as a scientific and objective study of people in society, the study of social institutions and processes. Sociology seeks to answer questions about the possible community, how it works and why it survives. This description will explain the ways in which humans adapt themselves to the specificities of society, the image of the mechanism of socialization, the cultural learning process by which individuals are allocated to and accept certain roles in the social structure. In addition, sociology also involves dealing with gradual and revolutionary social changes with the consequences of the change (Damono, 1978). One of the literary works that can be studied with literary sociology is novel. Griswold (2000) has explored the impact of system production on the content of literary works. The study of sociology of literature that has been done in various countries, especially Indonesia has also been done a lot to prove Griswold's statement. Griswold himself has done research that analyzes from the novels of the British and Nigerian publications which many take on traditional and urban themes. It is further explained that the results of Griswold's research show the Nigerian people often portrayed always struggling to deal with the problems of modernity (Singer, 2011).

The theme that is raised in seven short stories in the collection of short stories entitled Mata Yang Enak Dipandang by Ahmad Tohari is social life. In this collection of short stories, Ahmad Tohari seeks to describe the life of the lower classes with all the morals that result in social problems. Some of the social issues discussed in this collection are a form of Ahmad Tohari's concerns about the social problems occurring in his environment even in this country because until now, the problem has not been resolved yet. The social problem that is the theme in the Mata Yang Enak Dipandang is illustrated through its 
characters. Characteristic of Ahmad Tohari is lifting people's life down then the characters are also taken from "the bottom living".

The perspective of the five short stories in a collection of short stories of Mata Yang Enak Dipandang is diverse. Point of view contained in the seven short stories, among others, the point of view of the first person as the main perpetrator is in the short story "Penipu Keempat". In this short story the author positioned himself to describe and expose the various experiences he encountered. Literature has relevance to real-world problems, then literary teaching should be viewed as something important that deserves its proper place. If literary teaching is done in the proper way, literary teaching can make a great contribution to solving real problems that are difficult to solve in society.

The flow in the seven short stories in a collection of short stories Mata Yang Enak Dipandang is usually dominated by a mixture of grooves (back and forth). Of the seven short stories studied there are six short stories that use a mixed flow that is, "Bila Jebris di Rumah Kami", "Penipu Keempat", "Warung Penajem", "Kang Sarpin Minta Dikebiri", "Rusmi Ingin Pulang". One short story uses an advanced path that is "Mata Yang Enak Dipandang". Groove in the short story is generally started from the emergence of social problems in the community and then backward (flash back) told about the background of the emergence of social problems. Thats mixture is started from the telling of social problems caused by one of the characters, then readers are invited to remember what during this faced the main character causing social problems. Furthermore, at the end of the story, the narrator recounts such an event at the beginning of the story.

The point of view of the five short stories in a collection of short stories entitled Mata Yang Enak Dipandang are varied. There are viewpoints in seven short stories include a first person perspective as the protagonists featured in the short story "Cheater fourth". in this short story author positioned itself to render as well as expose the various experiences that she meets. Literature has relevance to the problems of the real world, then teaching literature should be viewed as something that important should be called appropriately. If the teaching of literature done the right way, then teaching literature can give great contributions to solving the real problems that are quite difficult to solve in the community.

A collection of short stories that Mata Yang Enak Dipandang by Ahmad Tohari, can be utilized in the study of literary appreciation for Class XI in Senior high school semester with the standard literary discourse understanding competence through reading poetry and short stories in the aspects of reading and basic competence that is analyzing the intrinsic elements of a short story linkages with everyday life. Teachers can observe the involvement of learners during a learning session, whether the learners being active or not. Psychomotor domain associated with subsequent development of learners in applying the values obtained from the results of reading the works of dealerships in everyday life. In line with the Charles b. Glenn (1999) which declared the formation of the character originated from the school. Thus, subjects taught should contains characters that can develop the abilities and skills of the student. This was added by one of the researchers, research subjects are Indonesia language and literature. Readings of literature such as novels, can be a means of forming the character of students. This Penganalisisan to improve the students ' ability and adds to the understanding of the students in the field of literature.

By utilizing a collection of short stories entitled Mata Yang Enak Dipandang by Ahmad Tohari, learners can make a collection of short stories In good Eye as intrinsic elements to discuss studies associated with daily life as appropriate with basics competency. Learners can take the values of humanity by understanding the themes and contents thoroughly.

\section{Conclusions}

Mata Yang Enak Dipandang is short short story-laden social issues and aspects will character education. This can be shown from elements of intrinsic and extrinsic featured in the short story, which in this case is examined with genetic structuralism approach. The unity of this study that eventually became the literary Sociology Studies produce that short story Mata Yang Enak Dipandang has the potential to serve as a teaching material because of charges that aspect of the problem of educational value of social and characters may be taken as a form of the implications of a literary work that is realized from the community and then returned to the community also benefits. 


\section{Acknowledgement}

Thanks the author to say to Prof. Dr. Suyitno, M.Pd. as the counselor and Dr. Muhammad Rohmadi, M. Hum. as a co-counselor so that the research can be completed. This research is part of the thesis research that is used as a requirement to get the magister degree.

\section{References}

Abrams, M. H. A Glossary of Literary Terms. New York: Holt, Rinehart et Winston, inc, 1981.

Albertazzi, Silvia. "A Comparative Essay on The Sociology of Literature: Alice Munro"s „Unconsummated Relationships"”. Journal of The Short Story 2.3 (2010): 100-112.

Asri, Y. "Analisis Sosiologis Cerpen Si Padang Karya Ardini Pangastuti B. N." dalam Jurnal Humaniora 23.3 (2011) : 245-255.

Damono, S. D. Sosiologi Sastra: Sebuah Pengantar Ringkas. Jakarta: Pusat Pembinaan dan Pengembangan Bahasa Depdikbud, 1978.

Damono, S. Sosiologi Sebuah Pengantar Ringkas. Jakarta: Departemen Pendidikan dan Kebudayaan, 1979.

Endraswara, S. Pengantar Sosiologi Sastra. Yogyakarta: Pustaka Pelajar, 2008.

Faruk. Pengantar Sosiologi Sastra. Yogyakarta: Pustaka Pelajar, 2010.

Glenn, Charles L. "Character Building and Freedom in Education." Europan Journal for

Education Law and Policy. 2.2 (1998) : 125-144.

Griswold. "The Writing on The Mud Wall: Nigerian Novels and The Imaginary Village" dalam American Sociological Review. 57 (1992) : 709-724.

Griswold. Bearing Witness: Readers, Writers, and The Novel in Nigeria. Princeton, NJ: PrincetonUniversity Press, 2000.

Kadir, Herson. "Ekspresi Pandangan Dunia Kelompok Sosial Pengarang dalam Novel Laskar Pelangi Karya Andrea Hirata". Jurnal Litera 12.1 (2013) : 134-136.

Kurniawan, H. Teori, Metode, dan Aplikasi Sosiologi Sastra. Yogyakarta: Graha Ilmu, 2012.

Leenhart, Jacques. "The Sociology of Literature: Some Stages in its History". International Social Science Journal. XIX (1967).

Miles, M dan Hubberman, A.M. Analisis Data Kualitatif: Buku Sumber Tentang Metode-Metode Baru. Jakarta: UI Press, 1992.

Nurgiyantoro, B. Teori Pengkajian Fiksi. Yogyakarta: Gadjah Mada University Press, 2005.

Pradopo, Rachmat D. Pengkajian Puisi. Yogyakarta: Gadjah Mada University Press, 1993.

Purwaningtyastuti, R. "Novels Works of Women Authors Indonesia of 2000's (Sociology Study of Literature, Gender Prespectives, and Educational Value)" dalam Journal of Education and Practice. 4.18 (2013) : 107-114.

Ratna, N. K. Teori, Metode, dan Teknik: Penelitian Sastra. Yogyakarta: Pustaka pelajar, 2015.

Saddhono, K. dan Rohmadi, M. "A Sociolinguistic Study on the Use of the Javanese Language in the Learning Process. International Education Studies 7.6 (2014) : 25-30.

Saddhono, K dan Supeni, S. The Role of Dutch Colonialism in the Political Life of Mataram Dynasty: A Case Study of the Manuscript of Babad Tanah Jawi. Asian Social Science 10.15 (2014):1-7.

Semi, M. Atar. Anatomi Sastra. Padang: Angkasa Raya, 1993.

Singer, A. E. "A Novel Approach: The Sociology of Literature, Children's Books, and Social Inequality” dalam International Journal of Qualitative Methods 10.4(2011) : 307-320.

Swingewood, A., dan Diana Lorenson. The Sociology of Literature. Paladine, 1972.

Teew, A. Sastra dan Ilmu Sastra: Pengantar Teori Sastra. Bandung: Pustaka Jaya, 1984.

Tohari, Ahmad. Mata Yang Enak Dipandang. Jakarta: Gramedia Pustaka Utama, 2015.

Waluyo, H. J. Apresiasi Puisi. Jakarta: Gramedia Pustaka Utama, 2002.. 